\title{
The Moderating Effect of Parent and Peer Influences on Hedonistic Behavior among Undergraduate Students in Malaysia
}

\author{
Siti Raba'ah Hamzah ${ }^{1}$, Steven Eric Krauss ${ }^{2}$, Turiman Suandi ${ }^{1}$, Azimi Hamzah ${ }^{2}$ \& Ezhar Tamam ${ }^{3}$ \\ ${ }^{1}$ Department of Professional Development and Continuing Education, Universiti Putra Malaysia, Malaysia \\ ${ }^{2}$ Institute for Social Science Studies, Universiti Putra Malaysia, Malaysia \\ ${ }^{3}$ Department of Communication, Universiti Putra Malaysia, Malaysia \\ Correspondence: Siti Raba'ah Hamzah, Department of Professional Development and Continuing Education, \\ Universiti Putra Malaysia, 43400 UPM, Serdang, Selangor, Malaysia. Tel: 60-13-394-4265. E-mail: \\ sitirabaahhamzah@gmail.com
}

Received: May 29, 2013 Accepted: June 26, 2013 Online Published: September 29, 2013

doi:10.5539/ass.v9n13p137 URL: http://dx.doi.org/10.5539/ass.v9n13p137

\begin{abstract}
This study assesses the moderating influence of parental and peer attachment on hedonistic behavior among a sample of youth in Malaysia. Using Bronfenbrenner's theory of human ecology and Armsden and Greenberg's attachment model, this study examines the direct and indirect influence of religiosity and worldview on the development of hedonistic behavior as moderated through parental and peer attachment. Drawing on a quantitative survey of 408 Malaysian university students $(M$ age $=21.0, S D=.40)$, structural equation modeling and path analysis findings reveal that peer attachment moderated the relationship between religiosity and worldview, and hedonistic behavior. The results further show the unique moderating effect of trust and alienation within peer attachment. The results are discussed in light of Malaysia's unique socio-cultural setting. Implications from the findings are also discussed.
\end{abstract}

Keyword: parental attachment, peer attachment, hedonistic behavior, youth development, religiosity, worldview

\section{Introduction}

Most previous research conducted to determine the influence of the relationship between parents and peer attachment was done in the context of family structure, which includes families with a single parent, divorced parents and career working parents. But a recent study shows that attachment with parents and peers not only affects family relationships and thus the parental role, but also the development of youth behavior. This gap is caused by factors that act as moderators (Eitle, 2005). Behaviorist researchers list various internal and external factors that account for aspects of psychology, sociology and the psychosocial domain. Based on this, the researchers conducted a study to bridge the gap in order to identify the moderating influence of psychosocial factors on the development of hedonistic behavior among youth in Malaysia.

In the context of youth behavioral development, hedonism has become central to the contemporary lifestyles of many youth (Thorpe, 2012; Andersson, 2011; Itafarida, 2008; Veenhoven, 2003). Sociological theory from Marx (1906), Weber (1920) and Durkheim (1984) in Bradford (2012) proposed the term contemporary social change in reference to changes of custom and tradition from pre-modernity to the modern industrial world that affect societies' cultural and behavioral development. There are two distinct aspects of ideal modernity, the technical aspect relating to skills and techniques and a normative aspect associated with values, beliefs and behaviors. Hedonistic behavior refers to one motivated by self-gratification in fulfilling biological and sociological needs, in which behaviors and decisions are based on personal desires. Individuals leading hedonistic lifestyles prioritize self-indulgence gained through activities that elicit excessive gratification, which lead to negative behaviors and diminished morality (Feldman, 2008; Veenhoven, 2003; Waterman, 1993). In this study, hedonistic behavior is characterized by openness to pleasurable experiences.

There are many concerns about hedonistic behavior. For societies, hedonistic behavior tends to erode social bonds as excessive pleasure-seeking makes people less sensitive to the needs of others, thus leading to moral decay. At the individual level, hedonistic behavior undermines health. Zimbardo \& Boyd (1999) argue that hedonistic behavior reflects attitudes toward time and life. Veenhoven (2003) argues that hedonistic behavior 
applies in particular to the pursuit of sensory pleasures such as drinking alcohol, sexual promiscuity, and undertaking risky activities to maximize pleasure.

Hedonistic lifestyles are not a new phenomenon in Malaysia. Hedonism has been shown to contribute to loafing and a variety of social problems among youngsters (Azam, 2005). This situation is markedly apparent among teenagers and emerging adults, including students, employed workers and unemployed individuals. Most of these issues stem from immoral activities that lead to the practice of hedonistic ways of life (Baba, 2009; Veenhoven, 2003; Beyers \& Peterson, 2000).

Youth is a phase of life whose definition varies. In Malaysia, youth comprises the age group between 15 to 40 years old. This is the largest group of Malaysians in comparison with children and adults, and totals more than 11.6 million people or 43.6 percent of the total population (Department of Statistics, 2010). Malaysia is undergoing a process of rapid development and modernization, which has involved subsequent changes to the socio-demographic and cultural environment. This has resulted in significant changes to patterns of social development where the youth have had to adapt to a changing developmental environment. As a result, they are reflexively influenced by their environment and at the same time, as agents of their own development, help contribute to that environment (Bronfenbrenner, 1989). A study of youth subculture conducted by Universiti Putra Malaysia (UPM) showed that the values of individualism and materialism, religious orientation, the influence of foreign culture, identity changes, communication behavior and media habits, activity at the time leisure, health habits and career aspirations have all played a part in influencing changes to youth behavior (Azimi, Turiman \& Ezhar, 2000).

\section{Literature Review}

\subsection{Factors Influencing Youth Behavior}

Ecological systems theory provides a general framework for understanding interpersonal relations in the various settings that contribute to the behavioural development of youth. The first level of Bronfenbrenner's (1979) ecological model, the microsystem, focuses on the immediate environments in which youth have direct involvement. In the family microsystem the mother-child and father-child dyads have been understood as key relationships due to the role of parents as primary socializing agents (Grusec \& Kuczynski, 1997). The peer relationship is recognized as another microsystem that contributes to the development of children and adolescents. According to Bronfenbrenner's theoretical perspective, these proximal microsystemic processes unfold within the context of the broader macrosystem.

Youth behavior forms through the growth and development process in the human ecological system especially the environment (psychological, physical \& social) and these core entities serve as youth's initial platform to learn about the world. In reference to the theory of human ecology (Bronfenbrenner, 1989), young people experience the micro system through environmental factors such as family, peers, school and religious settings. These factors help to mold youth behavior.

\subsection{Parental Attachment}

Theoretically, attachment with parents is vital in nurturing, guiding and supporting healthy behavioral development among youth (Cook, Buehler \& Fletcher, 2012; Horwath, Lees \& Sidebotham, 2012). Parental attachment and youth development literatures have long recognized the importance of parenting to youth outcomes. Theoretical and empirical work has consistently linked effective parenting practices to youth well-being whereas ineffective parenting practices have been shown to predict unhealthy youth functioning. To date, studies show that healthy relationships with parents can be a key indicator of future well-being. This is especially true of those with positive characteristics (Ma \& Huebner, 2008; Arshat, Baharudin, Juhari \& Kahar, 2002) high academic achievement, good moral attitude (Abdorreza \& Rozumah, 2010) as well as a healthy emotional state. Attachment with parents is imperative in monitoring youth behavior. Parents as well as immediate family members are also responsible for providing basic needs, security and guidance as needed inputs for healthy physical and physiological development, which can also influence youths' social behavior (Bronfenbrenner, 1989).

Attachment to parents not only helps shape youth behavior but also helps young people deal with many of the social and emotional issues that they face. According to Bowlby (1982) and Ainsworth (1989), attachment can be characterized by a strong and loving relationship that binds parents to their children, which in turn leads to children developing trust in their parents. This connection between parents and children effectively helps the former mold their children's behavior and attitude in a certain way. This link also acts as the nurturing key in guiding and monitoring youth behavior over time. 
According to Wyn, Lantz and Harris (2012) a connection exists between parents' relationship with young people and their role in providing sociological needs in terms of material goods, emotional needs, social connection, and financial security based on healthy communication and trust. Strong familial bonds that rely on good communication, solidarity, and discipline have more impact in shaping youth behavior than sociodemographic factors like the size of the family, age, or circumstances around birth (Coombes, Allen, Marsh \& Foxcroft, 2009; McArdle, Wiegersma, Gilvarry, Kolte, McCarthy, Fitzgerald, Brinkley, Blom, Stoeckel, Pierolini, Michels, Johnson \& Quensel, 2002). Good communication at home is the most effective tool in achieving close and healthy relationships between parents and youth. Research shows that teenagers with confidence and trust in their relationship with their parents have strong resolution, good self-control and are able to manage themselves as well (Armsden \& Greenberg, 1987; Lewis, Woods \& Ellison, 1987).

\subsection{Peer Attachment}

Another important theoretical line of inquiry related to behavioral development and formation is that of peer attachment theory. According to Huang, Wang and Shi (2012) youths' attachment to peers can influence their behavior. In terms of socialization, peers compliment the family outside the home and are one of the transition mechanisms from childhood into the teenage years and adulthood. Friends provide social and academic support, and act as the platform to expand social circles. Peer influence also helps to shape youth personality and individuality (Suzana, 2008).

Research shows that healthy peer relationships have a positive psychological influence on youth (Durlak, Weissberg \& Pachan, 2010; Piaget, 1965). Peer relationships contribute to the development of values that generate happiness and self-confidence, which in turn results in positive attitudes and behaviors. According to Armsden and Greenberg (1987), attachment with peers occurs in the form of three dimensions: trust, communication and alienation.

Despite the number of studies showing a positive relationship between peer relations and youth behavior, another body of work has indicated that the influence of peer relationships on behavior can be negative. Kandel (1978) reports that youth attitudes and behaviors mirror each other, and that peers elicit more negative and deviant behaviors compared to positive ones (Zahrt \& Lange, 2011; Albert \& Steinberg, 2011; Brechwald \& Prinstein, 2011). In their study, Tomé and Matos (2012) showed that relationships with peers engaging in violence and negative behaviors can negatively influence the behaviors of their friends. This is in line with several other studies showing that youth with friends involved in risky behaviors are more likely to be engaged in the same risky activities themselves (Glaser, Shelton \& Bree, 2010).

\subsection{Religiosity}

Religiosity has been cited as a major influence on the formation of behavior and personality (Raba, 2001) and as an emotional support (Fuziah, 2008) by increasing self-esteem (Al-Qardhawi, 1977), and enhancing overall happiness in life. The term religiosity as used in the West typically is limited to religious practice, rituals and prosocial activities. In Malaysia, Islam is the majority religion and in the Islamic context, religious life is considered a comprehensive way of life (Yazdani, 2009). Religiosity in the Islamic context is considered a foundation for spiritual competence and one of the main foundations of youth growth and development (Zullig, Ward \& Horn, 2006). However, past studies have shown that hedonistic behavior correlates negatively with religiosity, indicating that a lifestyle dictated by maximizing sensual pleasure is at odds with important inputs to positive youth development (Milfont, Andrade, Pessoa \& Belo, 2008).

\subsection{Worldview}

Religious worldview is believed to have an influence on the religiosity formation of youth. According to Dewitt and Deckard (2003) there are three important factors which influence youth worldview which are theology, science, and age. Theological aspects will encourage the formation of a belief system to appreciate nature and participate in the cycles of the ecological model (Bronfenbrenner, 1989). Kearney (1974) mentioned that worldview is a culturally organized macro thought those dynamically inter-related basic assumptions of a people help to determine much of their behavior and decision making, as well as organizing much of their body of symbolic creations. The formation of a worldview is associated with cognition, learning, perception and behavior, and environment. The driving force behind the development of a worldview is the need to relate to the outside of the world. As aptly stated by Ross (1962) man's" experience is useless unless interpreted." Therefore, beginning from childhood, each person interacts with their physical and social environment, and through this myriad of environmental interactions, worldview presuppositions are unconsciously constructed. The process occurs over a long period of time, with the formative, young adult years being of most importance. Through the years of schooling, formal education contributes to worldview development; and in turn, a worldview provides a 
foundation upon which cognitive frameworks are built during the learning process.

\subsection{Parent and Peer Attachment as Moderating Factors}

Theory and research have suggested attachment with parents and peers can moderate young people's behavior in varying ways. Liu (2011) mentioned that relationships tend to be negative between parents and peers of youths involved in delinquency. Studies have also shown that youths suffering from depression and a negative outlook on life often have weak attachment to parents and peers. Research by Urberg, Luo, Pilgrim and Degirmencioglu (2003) confirms that attachment with parents and peers can be the moderating factor in determining youth involvement in delinquent behaviors and negative activities. The evidence suggests, therefore, that the stronger the attachment between parents and peers with youth, the less likely they will be involved in delinquent activities.

Research also illustrates that the more involved youth are with negative activities, the lower their attachment is to parents and peers. Lynam, Loeber and Stouthamer (2008) found that youth-parent relations moderated the relationship between youth behavior and juvenile activities among adolescents and emerging adults. Some of the contributing factors identified in building strong relationships with parents are skills in disciplining, monitoring and giving appropriate punishment to youth. A large body of research demonstrates the implications of negative relationships between parents and youth, including antisocial behaviors and a rise in social problems among youth (Eichelsheim, Kirsten, Buist, Dekovic, Wissink, Frijns, Lier, Koot \& Meeus, 2010).

Significant evidence exists indicating that religiosity and worldview are major contributors to youth behavior. Attachment to parents and peers has also been shown to play an important moderating role in this relationship. Despite a vast literature on youth behavior, specific studies related to hedonistic behaviors and lifestyles are still wanting, particularly from non-Western settings. Therefore, drawing on the theory of human ecology (Bronfenbrenner, 1989), this study set out to determine the moderating effect of parental and peer attachment (Bowlby, 1982; Ainsworth, 1989) on hedonistic behavior among students in higher education institutions in Malaysia. We hypothesized that parental and peer attachment would have a moderating effect on the relationship between religiosity and worldview, and hedonistic behavior.

\section{Method}

\subsection{Instrumentation}

The study used a survey questionnaire divided into five parts: demographics, worldview, religiosity, parental and peer attachment and hedonistic behavior. Measures included self-administered questionnaires adapted from Krauss, Azimi, and Fazilah (2007), Deckard and Dewitt (2003), Armsden and Greenberg (1987), and Zimbardo and Boyd (1999).

The Universal Religiosity Personality Inventory (Krauss, Azimi \& Fazilah, 2007), measures religiosity in the context of prosocial and ritual behaviors. Sample items on the prosocial behavior scale included: 'I immediately apologize if I wrong someone', 'I try to smiles as much as possible', and 'I speak politely to my parents'. For the ritual behavior scale, sample items included: 'I make effort to deepen my understanding of law/rules/teaching/precepts of my religion', 'I invite others to obligatory prayer' and 'I perform my work duties enthusiastically because of my religion'. Although many studies conducted in the West have included the prosocial and ritual behaviors little attempt has been made to measure religiosity in the context of a multiracial community such as in Malaysia.

The worldview measures in this study was used and adaption from Deckard and Dewitt (2003). Samples item of theology scale included: "I believe there is only one God is the source of all creation", I believe that man is the best creation of God", I believe that God knows all the developments taking place in this world", "I believe that my future was determined", : and for the science scale included: "I believe people need to change for the better in the life", "I believe every weakness there is good", "I believe in time, space and opportunity always exists in life", "I believe I can identify the good and the bad things in my life", "I believe life has a specific purpose", and "I always think about the moment of my death".

Zimbardo Time Perspective Inventory (Zimbardo \& Boyd, 1999) is a fundamental dimension in the construction of present hedonistic characterized an orientation toward present enjoyment, pleasure and excitement. It reflect a hedonic risk taking attitude toward time and life and includes such diverse items as "takings risks keeps my life from becoming boring", I do things impulsive", "I often follow my heart more than my head", and "when listening to my favorite music, I often lose all track of time", and It is important to put excitement in my life". Evident from much research reported the combination of time perspective inventory and religiosity personality inventory remains a uniquely independent contribution to many factors which relate to the youth behavioral 
development (Kroger, 2000).

The Inventory for Parent and Peer Attachment (IPPA, Armsden \& Greenberg, 1987) was developed to measure attachment in older adolescents. It assesses the positive and negative affective and cognitive dimensions of adolescent relationships with their parents and peers. For each of the 28 items assessing parent attachment and the 25 items assessing peer attachment, respondents are required to rate the degree to which each item is true for them on a five-point scale ranging from 'Almost always or always true' to 'Almost never or never true'. The items in each of the scales (i.e. parent, peer) were demonstrated through principal components analysis to cluster into three factors (trust; communication; anger \& alienation). For the parental and peer form, the first factor (trust) was interpreted in terms of "understanding and respect and mutual trust", the second factor (communication) in terms of "the extent and quality of verbal communication" and the third factor (alienation) in terms of "feelings of alienation and isolation". In the present study, the IPPA was scored in accordance with directions provided by Armsden and Greenberg (1987).

\subsection{Population and Sampling}

Undergraduate students of higher education institutions in Malaysia comprised the target population for this study. A stratified random sampling technique was used to ensure representativeness of the chosen sample. A total of 408 respondents from public and private universities were selected. The mean age of the participants was 21 years $(S D$ $=.40)$, with a range of 18 to 22 years. The sample consisted of $188(46.1 \%)$ males and $220(53.9 \%)$ females with the majority 316 (77.5\%) living in towns/suburbs, and 92 (22.5\%) from urban areas.

\subsection{Data Collection}

Data was collected using the survey method.

\subsection{Data Analysis}

Descriptive analysis including comparison of mean scores was conducted for religiosity, worldview, parental and peer attachment and hedonistic behavior. Structural equation modeling (SEM) and path analysis was conducted to determine the moderating effect of parental and peer attachment on the relationship between religiosity and worldview, and hedonistic behavior.

\section{Results and Discussion}

Results of the SEM for the direct model indiecate that the model fits the data. Following general guidelines for fit indices, Goodness-of-fit statistic (GFI), Root Mean Square of Error Approximation (RMSEA) for Absolute Fit Measure, Normed Fit Index (NFI), Tucker-Lewis Index (TLI) and Comparative Fit Index (CFI) for Incremental Fit Measure, Normed Chi Square ( $\chi 2 / \mathrm{df}$ ) for Parsimonious Fit Measure (Hair, Black, Babin \& Anderson, 2010; Byrne, 2010; Hu \& Bentler, 1999; Browne \& Cudeck, 1993) the test of model fit for the study variables is presented in Table 1.

Table 1. Test of model fit indices for all variables

\begin{tabular}{lllllll}
\hline Index GOF & $\chi 2 / d f / C M I N$ & GFI & CFI & IFI & TLI & RMSEA \\
\hline Value & 1.700 & .823 & .901 & .908 & .907 & .041 \\
\hline
\end{tabular}

The results show that the model fit the data with the values, $\chi^{2}=2632.737, p=.000, \chi 2 / \mathrm{df}=1.700, \mathrm{CFI}=.901$, $\mathrm{IFI}=.908, \mathrm{TLI}=.907, \mathrm{RMSEA}=.041$. The RMSEA's $90 \%$ confidence interval was .05 to .08 . The CFI, IFI, TLI were all above. 90 indicating good fit.

The result of the hypothesis test shows that there is a significant relationship between religiosity and worldview on the development of hedonistic behavior. To test the moderating effect of parental and peers attachment on the development of hedonistic behavior, an overall structural model was developed of which the results indicated good model fit. The results of the moderation model show that $15 \%$ of the variance of parental and peer attachment influenced the development of hedonistic behavior.

Test for moderation effects showed a significant correlation with the measurement residuals model as compared to the unconstrained model. Chi-Square for the difference in degrees of freedom $(d f)$ was $6713-6320=393$. Both models were significant with a value of $p=.000(p<.05)$; the unconstrained model showed better fit than the measurement residuals model. Differences in $p$ values $(p<\alpha)$, Chi-Square $(\alpha 2)=1540.287$ (13919.731 12379.445), $d f=393, p=.000$, indicate a significant moderator effect in the overall model as shown in Table 2 . 
Table 2. Results of moderation test of parent and peer attachment on hedonistic behavior

\begin{tabular}{lllllll}
\hline Model & Chi-Square & $\boldsymbol{d f}$ & $\boldsymbol{p}$ & CMIN/DF & Chi-Square & Test of moderating \\
\hline Measurement residuals & 13919.731 & 6713 & .000 & 2.074 & & \\
Unconstrained model & 12379.445 & 6320 & .000 & 1.959 & 1540.287 & $\begin{array}{l}\text { Significant and moderate } \\
\text { effects }\end{array}$ \\
\hline
\end{tabular}

Results of the multi-group test for moderation effects are shown in Table 3. The table indicates that the moderating effect of parental attachment on hedonistic behavior was not significant. In addition, the results of the moderating effect of peer attachment on the relationship between religiosity and worldview and hedonistic behavior was significant. The result shows that trust for group 1 was not significant $(\beta=-.151$, Sig $=.249)$, but was significant for group $2(\beta=.152, \operatorname{Sig}=.002)$, and the alienation dimension for group 1 was not significant $(\beta$ $=-.034$, Sig $=.763)$, but for group 2 was significant $(\beta=-1,024$, Sig $=.000)$. According to Hair et al., $(2010)$, if one of the groups tested is significant, and one is not significant, then there are moderation effects. Therefore, these studies show that peer attachment moderates the influence of the religiosity and worldview on hedonistic behavior among youth.

Table 3. Results of moderation test of parental and peers' attachment on hedonistic behavior between religiosity and worldview

\begin{tabular}{llllll}
\hline Construct & Estimates & $\boldsymbol{\beta}$ & C.R. & P & Result \\
\hline Parent trust & & & & & \\
$\quad$ Parent (high) & -3.110 & -1.062 & -3.544 & .000 & Not moderator \\
$\quad$ Parent (low) & -2.220 & -1.565 & -2.328 & .020 & \\
Parent communication & & & & & \\
$\quad$ Parent (high) & .148 & .109 & 1.600 & .110 & Not moderator \\
$\quad$ Parent (low) & -.206 & -.132 & -1.012 & .312 & \\
Parent alienation & & & & & \\
$\quad$ Parent (high) & -.023 & -.021 & -.204 & .839 & Not moderator \\
$\quad$ Parent (low) & -4.865 & -1.960 & -1.684 & .092 & \\
Peer trust & & & & & \\
$\quad$ Peer (high) & -.376 & -.151 & -1.152 & .249 & Significant - moderator \\
$\quad$ Peer (low) & .262 & .152 & 3.147 & .002 & \\
Peer alienation & & & & & \\
$\quad$ Peer (high) & -.036 & -.034 & -.301 & .763 & Significant - moderator \\
$\quad$ Peer (low) & -2.371 & -1.024 & -3.354 & .000 & \\
\hline
\end{tabular}

\section{Discussion}

Results from the moderating analysis shows that there is no direct affect from attachment with parents on hedonistic behavior among youth. The outcome shows that attachment with parents fits Bowlby (1982) and Ainsworth's (1987) theory that strong parental attachment with children leads to the strengthening of morality and positive behavior among children (Ma \& Huebner, 2008; Zarinah, Rozumah, Rumaya \& Rojanah, 2002). The study also confirms past research results that strong relationships with parents leads to positive behaviors. Research also shows that the stronger the attachment with parents, the less likely youths will be involved in hedonistic behaviors, such as consuming alcohol and excessive drug abuse (Clark, Belgrave \& Abell, 2012). The outcome further demonstrates two dimensions in measuring the strength of parental and peer attachment, which are trust and effective communication in building a healthy relationship with parents. This result is in accordance with the findings of Lynam, Loeber and Stouthamer (2008) in deciding the factors that contribute positively to 
the shaping of attachment with parents. Some of the factors include trust, good communication, effective discipline methods, careful monitoring, and appropriate punishment by parents to youth.

Theories of social learning (Bandura, 1977) and the ecological model of human development by Bronfenbrenner (1999) link attachment with peers to their interaction in social settings. This study shows that attachment with peers had a negative moderating effect on youth hedonistic behaviors, through peer trust and alienation. Young people who lack trusting relationships with their peers and feel alienated were more likely to engage in hedonistic behaviors. This result also supports studies conducted in the West, which have shown an association between attachment with peers and deviant behaviors (Kiesner, Poulin \& Dishion, 2010; Myrug \& Windle, 2009; Tajima, Herrenkohl, Moylan \& Derr, 2011), as well as a lack of social and emotional support. The results of this study also confirm those by Salzinger, Feldman, Rosario and Ng-Mak (2011), who showed that attachment with peers moderated the development of youth attitudes by exposing them to contemporary lifestyles subsequently leading to changes in their social behavior.

The aspects of trust and isolation with peers were significant in this study. Trust is vital among youth in establishing connections, primarily with socializing agents in their environment. The isolation factor in attachment with peers is also an essential aspect and this is because the maturing process happens simultaneously with changes in emotion, temperament and decision making (Hooper \& Newman, 2011).

Theory and research has suggested that prevailing concepts of peer attachment, such as those put forward by Arsmden and Greenberg (1987) highlights the positive (Durlak, Weissberg \& Pachan, 2010; Piaget, 1965) and negative (Tomé \& Matos, 2012; Zahrt \& Lange, 2011; Albert \& Steinberg, 2011; Brechwald \& Prinstein, 2011; Glaser, Shelton \& Bree, 2010) aspects of the relationship. The results of this study further support the prevailing argument that attachment relationships are an important moderating factor - in this case negatively - in the development and shaping of hedonistic behaviors among youth.

\section{Limitations and Future Directions}

Several limitations of this study must be noted. A stratified sampling method framework was used and as such the findings cannot be generalized to youth outside of Malaysian universities. The study also relies exclusively on a cross-section sample using self-administered questionnaires. Therefore, the findings cannot be used to draw conclusions about future influences of psychosocial factors and moderation effects of parental and peer attachment on hedonistic behaviour.

In addition, although parental and peer attachment is indirectly assessed in the measurement, the inclusion of these factors as separate indicators may have strengthened the model. Armsden and Greenberg (1987) found that the relationship between parents and peers will improve psychological well-being in adolescence. Future research should incorporate parental and peer attachment as a mediator to facilitate the development of youth behavior.

Despite these limitations, the findings of this study contribute to a better understanding of how parental and peer attachment influences the development of hedonistic behaviour among selected youth in Malaysia. The findings can be useful to all relevant stakeholders working with university-age youth in Malaysian, who are responsible for their behavioral development.

\section{References}

Ainsworth, M. S. (1989). Attachments beyond infancy. American Psychologist, 44(4), 709-716. http://dx.doi.org/10.1037/0003-066X.44.4.709

Albert, D., \& Steinberg, L. (2011). Peer influences on adolescent risk behavior. In M. T. Bardo, D. H. Fishbein \& R. Milich (Eds.), Inhibitory control and drug abuse prevention: From research to translation. New York: Springer. http://dx.doi.org/10.1007/978-1-4419-1268-8_11

Al-Qardhawi. (1997). Sharicah al-lslam salihah li al-tatbiq fi kull zaman wa makan. Kaherah: Maktabah Wahbah.

Andersson, J. (2011). Vauxhall's post-industrial pleasure gardens: 'Death wish' and hedonism in 21st-century London. Urban Studies, 48, 85-100. http://dx.doi.org/10.1177/0042098009360238

Armsden, G. C., \& Greenberg, M. T. (1987). The inventory of parent and peer attachment: Individual differences and their relationships to psychological well-being in adolescence. Journal of Youth and Adolescence, 16, 427-454. http://dx.doi.org/10.1007/BF02202939

Arshat, Z., Baharudin, R., Juhari, R., \& Kahar, R. (2002). Parenting behavior and child behavioral adjustment in families at risk in rural areas. Pertanika Journal of Social Sciences \& Humanities, 10(2), 165-178. 
Azimi, H., Turiman, S., \& Ezhar, T. (2000). Lifestyle and thinking style of youth in national development, youth facing the new millennium (57-61). Putrajaya: Ministry of Youth and Sports Malaysia.

Baba, S. (2009). Mindset. Kuala Lumpur: Alaf 21 Sdn. Bhd.

Bandura, A. (1977). Social learning theory. Englewood Cliffs, NJ: Prentice-Hall.

Beyers, M. S., \& Peterson, M. J. (2000). A contradiction in terms: Hedonismetic altruism. The General Psychologist, 35, 78-80.

Bowlby, J. (1982). Attachment and loss (2nd ed.). New York: Basic Books.

Bradford, S. (2012). Sociology, Youth and Youth Work Practice. Basingstoke. Palgrave Macmillan.

Brechwald, W. A., \& Prinstein, M. J. (2011). Beyond homophily: A decade of advances in understanding peer influence processes. Journal of Research on Adolescence, 21(1), 166-179. http://dx.doi.org/10.1111/j.1532-7795.2010.00721.x

Bronfenbrenner, U. (1979). The ecology of human development: Experiments by nature and design. Cambridge, MA: Harvard University Press.

Bronfenbrenner, U. (1989). Ecological systems theory. In R. Vasta (Ed.), Six theories of child development: Revised formulations and current issues (pp.187-250). Greenwich, CT: JAI Press.

Browne, M. W., \& Cudeck, R. (1993). Alternative ways of assessing model fit. In K. A. Bollen \& J. S. Long (Eds.), Testing structural equation models. Newbury Park, CA: Sage.

Byrne, B. M. (2010). Structural equation modeling with AMOS: Basic concepts, applications, and programming (2nd ed.). Routledge Academy: New York.

Clark, T. T., Belgrave, F. Z., \& Abell, M. (2012). The mediating and moderating effects of parent and peer influences upon drug use among African American adolescents. Journal of Black Psychology, 38(1), 52-80. http://dx.doi.org/10.1177/0095798411403617

Cook, E. C., Buehler, C., \& Fletcher. (2012). A process model of parenting and adolescents' friendship competence. Social Development, 21(3), 461-481. http://dx.doi.org/10.1111/j.1467-9507.2011.00642.x

Coombes, L., Allen, D., Marsh, M., \& Foxcroft, D. (2009). The strengthening families programme (sfp) 10-14 and substance misuse in Barnsley: The perspectives of facilitators and families. Child Abuse Review, 18, 41-59. http://dx.doi.org/10.1002/car.1055

Deckard, S., \& DeWitt, D. (2003). Worldview studies book one: Developing a Creator-centered worldview. Ramona, CA: Vision Publishing.

Department of Statistics Malaysia. (2010). Malaysian Population Statistic, 2010.

Durlak, J. A., Weissberg, R. P., \& Pachan, M. (2010). A meta-analysis of after-school programs that seek to promote personal and social skills in children and adolescents. American Journal of Community Psychology, 45(3-4), 294-309. http://dx.doi.org/10.1007/s10464-010-9300-6

Eichelsheim, V. I., Buist, K. L., Deković, M., Wissink, I. B., Frijns, T., Lier, P. A. C., Koot, H. M., \& Meeus, W. (2010). Associations among the parent-adolescent relationship, aggression and delinquency in different ethnic groups: A replication across two Dutch samples. Social Psychiatry and Psychiatric Epidemiology, 45(3), 293-300. http://dx.doi.org/10.1007/s00127-009-0071-z

Eitle, D. (2005). The moderating effects of peer substance use on the family structure-adolescent substance use association: Quantity versus quality of parenting. Addictive Behaviors, 30, 963-980. http://dx.doi.org/10.1016/j.addbeh.2004.09.015

Feldman, F. (2008). Whole life satisfaction concepts of happiness. Theoria, 74(3), 219-238. http://dx.doi.org/10.1111/j.1755-2567.2008.00019.x

Glaser, B., Shelton, H. K., \& Bree, M. (2010). The moderating role of close friends in the relationship between conduct problems and adolescent substance use. Journal of Adolescent Health, 47, 35-42. http://dx.doi.org/10.1016/j.jadohealth.2009.12.022

Grusec, J. E., \& Kuczynski, L. (1997). Parenting and the Internalization of Values: A Handbook of Contemporary Theory. New York: Guilford Press.

Hair, J. F. J., Black, W. C., Babin, B. J., \& Anderson, R. E. (2010). Multivariate data analysis (7th ed.). Saddle River, NJ: Prentice Hall. 
Hooper, L. M., \& Newman, C. R. (2011). Exploring the relations between parent depressive symptoms, family religious involvement, and adolescent depressive symptoms: A test of moderation. Counseling and Values, 55(2), 210-227. http://dx.doi.org/10.1002/j.2161-007X.2011.tb00033.x

Horwath, J., Lees, J., \& Sidebotham, P. (2012). The influence of religion on adolescent family life in England: An explanatory study of the views of young people and parents. Social Compass, 59(2) 257-275. http://dx.doi.org/10.1177/0037768612440967

$\mathrm{Hu} \&$ Bentler. (1999). Cutoff criteria for fit indexes in covariance structure analysis: Coventional criteria versus new alternatives. Structural Equation Modeling, 6(1), 1-55. http://dx.doi.org/10.1080/10705519909540118

Huang, Y., Wang, L., \& Shi, J. (2012). How Attachment Affects the Strength of Peer Influence on Adolescent Consumer Behavior. Psychology \& Marketing, 29(8), 558-567. http://dx.doi.org/10.1002/mar.20543

Itafarida. (2008). The impact of sociocultural changes on the youth? Achievement orientation in Fitzgerald? The Beautiful and Damned, 10(2), 146-153. Retrieved August 12, 2012, from http://www.citeulike.org/user/d_van_h/author/Itafarida

Jaafar, J. L. S. (2008). Introduction to children and adolescents psychology. Shah Alam: Arah Pendidikan Sdn. Bhd.

Kandel, D. B. (1978). Homophily, selection and socialization in adolescent friendships. Am. J. Sociol., 84, 427-436. http://dx.doi.org/10.1086/226792

Kearney, M. (1974). World View Theory and Study. Annual Review of Anthropology, 4, 247-270. http://dx.doi.org/10.1146/annurev.an.04.100175.001335

Kiesner, J., Poulin, F., \& Dishion, T. J. (2010). Adolescent substance use with friends: Moderating and mediating effects of parental monitoring and peer activity contexts. Merrill-Palmer Quarterly, 56(4), 529-556. Wayne State University Press. http://dx.doi.org/10.1353/mpq.2010.0002

Kordi, A., \& Baharudin, R. (2010). Parenting attitude and style and its effect on children's school achievements. International Journal of Psychological Studies, 2(2).

Krauss, S. E., Azimi, H., \& Fazilah, I. (2007). Adaptation of a Muslim religiosity scale for use with four different faith communities in Malaysia. Review of religious research, 49(2), 147-164. Retrieved February 28, 2012, from http://www. jstor. org /stable/ 20447486

Kroger, J. (2000). Identity development: Adolescence through adulthood. Newbury Park, CA: Sage.

Lewis, F. M., Woods, N. F., \& Ellison, E. (1987). Family impact study, Unpublished report, University of Washington, R01-NUO1000 Division of Nursing, Public Health Service.

Liu, R. X. (2011). Strain as a moderator of the relationship between parental attachment and delinquent participation: A China study. International Criminal Justice Review, 21(4), 427-442. http://dx.doi.org/10.1177/1057567711431127

Lynam, D. R., Loeber, R., \& Stouthamer-Loeber, M. (2008). The stability of psychopathy from adolescence into adulthood: The search for moderators. Criminal Justice and Behavior, 35(2), 228-243. http://dx.doi.org/10.1177/0093854807310153

Ma, C. Q., \& Huebner, E. S. (2008). Attachment relationships and adolescents' life satisfaction: Some relationships matter more to girls than boys. Psychology in the Schools, 45(2). 177-190. http://dx.doi.org/10.1002/pits.20288

McArdle, P., Wiegersma, A., Gilvarry, E., Kolte, B., McCarthy, S., Fitzgerald, M., Brinkley, A., Blom, M., Stoeckel, I., Pierolini, A., Michels, I., Johnson, R., \& Quensel, S. (2002). European adolescent substance use: The roles of family structure, function and gender. Addiction, 97(3), 329-336. http://dx.doi.org/10.1046/j.1360-0443.2002.00066.x

Milfont, T. L., Andrade, P. R., Belo, R. P., \& Pessoa, V. S. (2008). Testing Zimbardo Time Perspective Inventory in a Brazilian sample. Interamerican Journal of Psychology, 42, 49-58.

Mrug, S., \& Windle, M. (2009). Moderators of negative peer influence on early adolescent externalizing behaviors: The roles of individual behavior, parenting, and school connectedness. Journal of Early Adolescence, 29, 518-540. http://dx.doi.org/10.1177/0272431608324473

Piaget, J. (1965). The moral judgment of the child. Translated by T. A. Brown \& C. E. Kaegi. Palo Alto, CA: Annual Reviews. 
Rahman, A. A. A. (2005). Strategic face the challenges of globalization. Paper presented at Malaysian Hall. Abbasiah, Kaherah organized by Yadim, Ypeim, Inmind, Mas, Abim Mesir and Malaysian Student Department Cairo, 15 - 16 November 2005.

Ross, R. (1962). Symbols and civilization: science, morals, religion, art. New York: Harcourt, Brace \& World, Inc.

Salzinger, S., Feldman, R. S., Rosario, M., \& Ng-Mak, D. S. (2010). Role of parent and peer relationships and individual characteristics in middle school children's behavioral outcomes in the face of community $\begin{array}{llll}\text { violence. Journal of Research on Adolescence, 21(2), 395-407. } & \text {. }\end{array}$ http://dx.doi.org/10.1111/j.1532-7795.2010.00677.x

Tajima, E. A., Herrenkohl, T. I., Moylan, C. A., \& Derr, A. S. (2010). Moderating the effects of childhood exposure to intimate partner violence: The roles of parenting characteristics and adolescent peer support. Journal of Research on Adolescence, 21(2), 376-394. http://dx.doi.org/10.1111/j.1532-7795.2010.00676.x

Thorpe, H. (2012). Sex, drugs and snowboarding: Legitimate definitions of taste and lifestyle in a physical youth culture. Leisure Studies, 31(1), 33-51. http://dx.doi.org/10.1080/02614367.2011.596556

Tomé, G., Matos, M. G., Simões, C., Camacho, I., \& Diniz, J. A. (2012). How can peer group influence the behavior of adolescents: Explanatory model. Global Journal of Health Science, 4(2), 26-35. http://dx.doi.org/10.5539/gjhs.v4n2p26

Urberg, K. A., Luo, Q., Pilgrim, C., \& Degirmencioglu, S. M. (2003). A two-stage model of peer influence in adolescent substance use: Individual and relationship-specific differences in susceptibility to influence. Addictive Behaviors, 28, 1243-1256. http://dx.doi.org/10.1016/S0306-4603(02)00256-3

Veenhoven, R. (2003). Hedonism and happiness. Journal of Happiness Studies, 4(4), 437-457. http://dx.doi.org/10.1023/B:JOHS.0000005719.56211.fd

Waterman, A. S. (1993). Developmental perspectives on identity formation. In J. E. Marcia, A. S. Waterman, D. R. Matteson, S. L. Archer \& J. L. Orlofsky (Eds.), Ego identity: A handbook for psychosocial research. New York: Springer-Verlag. http://dx.doi.org/10.1007/978-1-4613-8330-7_3

Wyn, J., Lantz, S., \& Harris, A. (2012). Beyond the 'transitions' metaphor: Family relations and young people in late modernity. Journal of Sociology, 48, 3-22. http://dx.doi.org/10.1177/1440783311408971

Yazdani, E. (2009). Globalization and the role of Islam in the post-Soviet Central Asia. Turkish Journal of International Relations, $8(2)$.

Yusof, S. F. (2008). Kesan penggunaan rakaman audiovisual alam semulajadi yang diiringi surah Yasin ke atas ketenangan jiwa. Thesis (Unpublished). Serdang: Universiti Putra Malaysia.

Zahrt, D. M., \& Lange, M. D. (2011). Aggressive behavior in children and adolescents. Pediatrics in Review, 32, 325. http://dx.doi.org/10.1542/pir.32-8-325

Zimbardo, P. G., \& Boyd, J. N. (1999). Putting time in perspective: A valid, reliable, individual-differences metric. Journal of Personality and Social Psychology, 77, 1271-1288. http://dx.doi.org/10.1037/0022-3514.77.6.1271

Zullig, K. J., Ward, R. M., \& Horn, T. (2006). The association between perceived spirituality, religiosity, and life satisfaction: The mediating role of self-rated health. Social Indicators Research, 79(2), 255-274. http://dx.doi.org/10.1007/s11205-005-4127-5

\section{Copyrights}

Copyright for this article is retained by the author(s), with first publication rights granted to the journal.

This is an open-access article distributed under the terms and conditions of the Creative Commons Attribution license (http://creativecommons.org/licenses/by/3.0/). 